\title{
Soil Erosion and Gaseous Emissions
}

\section{Rattan Lal}

Carbon Management and Sequestration Center, the Ohio State University, Columbus, OH 43210, USA; lal.1@osu.edu

Received: 27 March 2020; Accepted: 14 April 2020; Published: 17 April 2020

\begin{abstract}
Accelerated soil erosion by water and wind involves preferential removal of the light soil organic carbon (SOC) fraction along with the finer clay and silt particles. Thus, the SOC enrichment ratio in sediments, compared with that of the soil surface, may range from 1 to 12 for water and 1 to 41 for wind-blown dust. The latter may contain a high SOC concentration of $15 \%$ to $20 \%$ by weight. The global magnitude of SOC erosion may be $1.3 \mathrm{Pg} \mathrm{C} / \mathrm{yr}$. by water and $1.0 \mathrm{Pg} \mathrm{C} / \mathrm{yr}$. by wind erosion. However, risks of SOC erosion have been exacerbated by the expansion and intensification of agroecosystems. Such a large magnitude of annual SOC erosion by water and wind has severe adverse impacts on soil quality and functionality, and emission of multiple greenhouse gases (GHGs) such as $\mathrm{CO}_{2}, \mathrm{CH}_{4}$, and $\mathrm{N}_{2} \mathrm{O}$ into the atmosphere. SOC erosion by water and wind also has a strong impact on the global $\mathrm{C}$ budget (GCB). Despite the large and growing magnitude of global SOC erosion, its fate is neither adequately known nor properly understood. Only a few studies conducted have quantified the partitioning of SOC erosion by water into three components: (1) redistribution over land, (2) deposition in channels, and (3) transportation/burial under the ocean. Of the total SOC erosion by water, $40 \%-50 \%$ may be redistributed over the land, $20 \%-30 \%$ deposited in channels, and $5 \%-15 \%$ carried into the oceans. Even fewer studies have monitored or modeled emissions of multiple GHGs from these three locations. The cumulative gaseous emissions may decrease at the eroding site because of the depletion of its SOC stock but increase at the depositional site because of enrichment of SOC amount and the labile fraction. The SOC erosion by water and wind exacerbates climate change, decreases net primary productivity (NPP) and use efficiency of inputs, and reduces soils $\mathrm{C}$ sink capacity to mitigate global warming. Yet research information on global emissions of $\mathrm{CH}_{4}$ and $\mathrm{N}_{2} \mathrm{O}$ at different landscape positions is not available. Further, the GCB is incomplete and uncertain because SOC erosion is not accounted for. Multi-disciplinary and watershed-scale research is needed globally to measure and model the magnitude of SOC erosion by water and wind, multiple gaseous emissions at different landscape positions, and the attendant changes in NPP.
\end{abstract}

Keywords: global carbon budget; soil organic carbon erosion; deposition; gaseous emissions; enrichment ratio; soil depletion; preferential removal

\section{Introduction}

As a natural geological process, soil erosion over eons has created the world's most fertile alluvial and aeolian (loess) soils. Acceleration of the natural erosion process by human activities, ever since the dawn of settled agriculture $\sim 12$ millennia ago, has caused the most severe environmental problems of the 21st century. Soil erosion, involving breakdown and transport of soil particles, requires energy, and a specific type of erosion depends on the source of energy (Figure 1). Water and wind are among the principal sources of energy, and thus major factors of erosion. Being a selective process, soil erosion removes and transports fine (i.e., clay and silt) and light (soil organic carbon or SOC) fractions. These three constituents (i.e., clay, silt, and SOC) are also key determinants of soil quality, and its capacity to provide numerous ecosystem services (ESs). However, these essential constituents 
are depleted over time in soils prone to accelerated erosion. The latter has plagued the Earth and humanity for millennia. The data based on the analysis of sediments from 600 lakes worldwide show that anthropogenic activities accelerated global soil erosion 4000 years ago [1]. Many once-thriving civilizations vanished because they treated their soil like dirt [2,3]. The current problem of accelerated soil erosion is driven by a rapid and an indiscriminate expansion of agroecosystems for feeding the growing population. Further, the problem of soil erosion is also exacerbated by anthropogenic global warming [4,5]. In addition to adversely impacting the wellbeing of 3.2 billion people [6], accelerated soil erosion is also polluting the environment (i.e., soil, water, and air). It affects and is affected by the present and will be aggravated by the projected climate change.

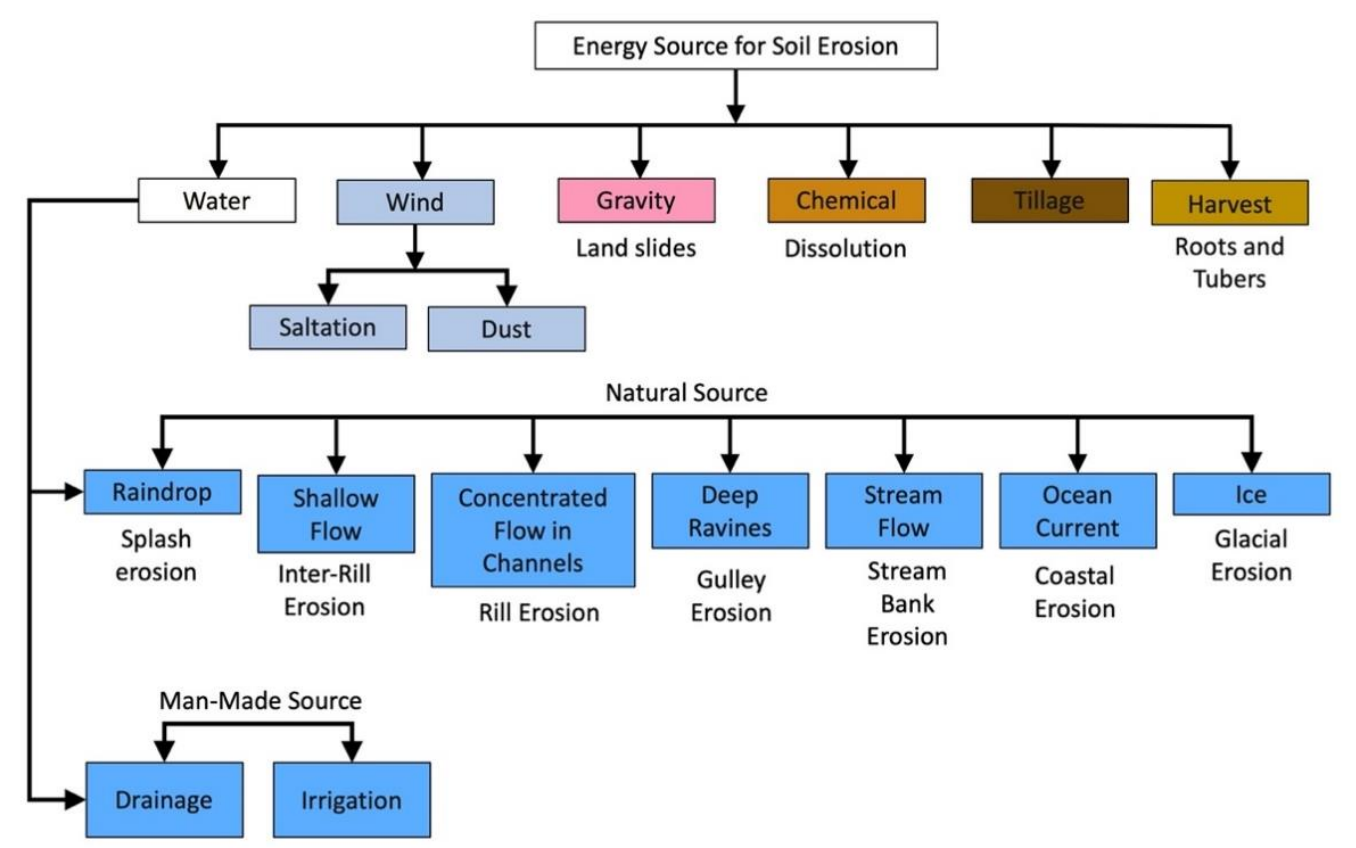

Figure 1. Types of soil erosion driven by source of energy.

Under natural ecosystems, SOC stock is a sink of atmospheric carbon dioxide $\left(\mathrm{CO}_{2}\right)$, and is protected against microbial processes through the formation of organo-mineral complexes and stable structural units or aggregates. Conversion of natural to managed ecosystems disrupts aggregates, exposes the hitherto protected SOC, and increases its vulnerability to transport by erosion and decomposition by microbial processes. Preferentially removed light SOC fraction is redistributed over the landscape, deposited in channels and transported to aquatic ecosystems and depressional sites (Figure 2). The labile SOC fraction is exposed to microbial processes when being transported, and following after redistribution and deposition phases of the erosion process. Furthermore, the historic land use based on extractive farming practices also mined off the SOC stock as a source of plant nutrients. Thus, soils of most agroecosystems are depleted of their original SOC stock. Consequently, soil quality is degraded, the capacity to perform ESs is impaired, and the environment (i.e., soil, water, air, and biodiversity) jeopardized. 


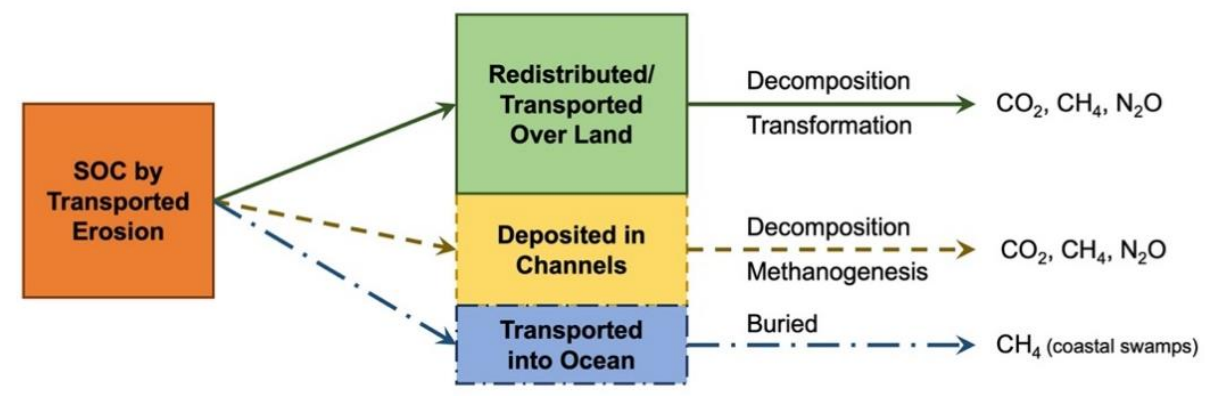

Figure 2. The fate of soil organic carbon transport by erosion. About $40 \%-50 \%$ may be redistributed over the land, $20 \%-30 \%$ may be deposited in channel, $5 \%-15 \%$ may be carried into the ocean, and about $15 \%-20 \%$ may be emitted into the atmosphere. However, the exact partition may vary among soil, climate, land use, and other site-specific factors. Whereas the cumulative emission of $\mathrm{CO}_{2}$ may decrease at the eroded site, it may increase at the transported and depositional zones.

The global magnitude of historic depletion of SOC by all processes may be as much as $135 \mathrm{Pg} \mathrm{C}$ [7]. Consequently, degraded and depleted soils also have a large carbon (C) sink capacity to reabsorb atmospheric $\mathrm{CO}_{2}$ into SOC stock upon conversion to a restorative land use and adoption of conservation-effective practices.

It is this potential of restoring the global SOC stock, for advancing food and climate security and strengthening soils' capacity to provide ESs, that sustainable soil management is receiving the attention of policymakers. Ever since the launch of the 4 Per Thousand (4P1000) initiative at COP 21 in Paris in 2015 [8], world soils have been on the global agenda as an option to sequester C and mitigate global warming. Such initiatives are aimed at achieving greenhouse gas (GHG) neutrality through low-carbon farming [9].

Transport of $\mathrm{C}$ by accelerated soil erosion at a global scale is one such process that impacts the emission of $\mathrm{CO}_{2}$, methane $\left(\mathrm{CH}_{4}\right)$, and nitrous oxide $\left(\mathrm{N}_{2} \mathrm{O}\right)$. The drastic increase in SOC erosion by anthropogenic activities poses a daunting challenge of assessing its impact on the global $\mathrm{C}$ budget (GCB) and GHG emissions. Therefore, it is important to credibly assess the mean annual flux of GHGs from soils during different erosional phases so that the magnitude of the carbon dioxide equivalent $\left(\mathrm{CO}_{2} \mathrm{eq}\right)$ can be estimated. Whereas the soil $\mathrm{C}$ transported by erosional processes comprises of $\mathrm{SOC}$ and soil inorganic $\mathrm{C}$ (SIC), the fate of SOC transported by water and wind erosion that impacts the emission of GHGs [10] is not understood. Therefore, the objectives of this article are to describe the effects of erosion on the emission of GHGs into the atmosphere, explain processes affecting gaseous emissions by soil erosion, describe generic options that can reduce risks of soil erosion and minimize the emission of GHGs, and identify researchable priorities. This article is based on the hypothesis that accelerated soil erosion is a source of major GHGs including $\mathrm{CO}_{2}, \mathrm{CH}_{4}$, and $\mathrm{N}_{2} \mathrm{O}$ during all three phases of the erosional process.

\section{Materials and Methods}

The literature is replete with articles on soil erosion by water and wind. Thus, the literature search was specifically focused on available information on the magnitude of SOC transported by water and wind erosion was collated from the Web of Science, Google, and other sources. The literature search involved journals dealing with basic and applied sciences. The focus included journals dealing with: (a) earth sciences such as Global Change Biology, Global Biogeochemical Cycles, Biogeosciences, Geomorphology, J. Geophysical Research, Earth Surface Processes and Landforms, Geochemistry, J. Geophysical Res., J. Hydrology, Aeolian Research, (b) popular journals such as Science, Nature, Philosophical Transactions of Royal Society, (c) environmental sciences including Env. International, Climatic Change, Ecosphere, (d) journals devoted to soil science including Soil Research, Geoderma, Soil Sci. Soc. Amer. J., Catena, European J. Soil Sci., Australian J. Soil Res., J. Soil and Water 
Conservation, and (e) those dealing with policy issues such as Land Use Policy, Science Policy, and Land Degradation and Development. Only those articles were selected for discussions in the present review which contained quantitative data on the magnitude of SOC or total carbon (TC) transported by erosional processes, and information on gaseous emissions at different landscape positions within an eroding landscape. While the literature searched is global, most of the articles addressing this theme were those published from the research done in the U.S.A., Europe, East Asia, Australia, and South America.

\subsection{Soil Erosion by Water: Transport, Redistribution, and Deposition of Soil Organic Carbon Over the Landscape}

Water erosion affects as much as 1.1 billion hectares (B ha) of the land area [11]. Available data on the magnitude of sediment load transported by world rivers are more credible [12] than that for the amount of soil moved by aeolian processes. The global land-ocean flux of sediment has reportedly increased from $14.0 \mathrm{Pg} / \mathrm{yr}$. ( $\mathrm{Pg}=$ peta gram $=1$ billion metric ton) during the pre-human era to the contemporary flux in the absence of reservoir trapping to $36.6 \mathrm{Pg} / \mathrm{yr}$. [12]. Sediments are enriched in SOC, and the global increase in sediment load may cause a strong increase in the transport of SOC, whose fate must be understood in relation to emissions of GHGs. Soil erosion on U.S. cropland increased by $\sim 17 \%$ over the 20th century through the expansion of the land area under agriculture [13]. The SOC fraction entrained in the shallow runoff is moved and redistributed over the landscape. Erosion of soil and SOC stock has direct and indirect effects on soil and environment quality, net primary productivity (NPP), and efforts to achieve land degradation neutrality or LDN (Figure 3). The magnitude of the effect of emissions of GHGs is governed by the pathways of SOC erosion. The fate of SOC being redistributed depends on how it is being moved by the fluvial processes and on the temperature and moisture regimes at the redistribution and depositional positions (Figure 2). Quantitative assessment of the movement of SOC over the landscape is essential to establishing the watershed level $C$ budget [14] that can be scaled up to the river basin and eventually to regional, national, or global scale. The magnitude of SOC erosion by fluvial processes varies widely (Table 1) depending on a range of factors. Important among these are climate [10,13], soil [15-17], terrain [18] and land use [13-15,19-23]. On the basis of some empirical data from 240 runoff plots studied over the entire rainy season from diverse global ecoregions, Mueller-Nedebock and Chaplot [18] estimated that the total amount of SOC displaced by sheet erosion from its source would be $1.32 \pm 0.20 \mathrm{Pg} \mathrm{C}$, or about $11.4 \%$ of the annual anthropogenic emission of $11.5 \mathrm{Pg} \mathrm{C}$ in 2019 [21]. Integrating all C fluxes for the EU agricultural soils, Lugato et al. The author of [24] estimated a net $\mathrm{C}$ loss or gain of $-2.28 \mathrm{Tg} \mathrm{CO}$ e/yr. and $+0.79 \mathrm{Tg} \mathrm{CO} \mathrm{CO}_{2}$ e/yr., and they argued that strong agricultural policies are needed to prevent or reduce soil erosion. Assessing and accounting for all the additional feedback and C fluxes due to displacement by erosion, Lugato et al. [15] estimated a net source of 0.92 to $10.0 \mathrm{Tg}$ C/yr. from agricultural soils in the European Union to the atmosphere over the period of 2016-2100. 


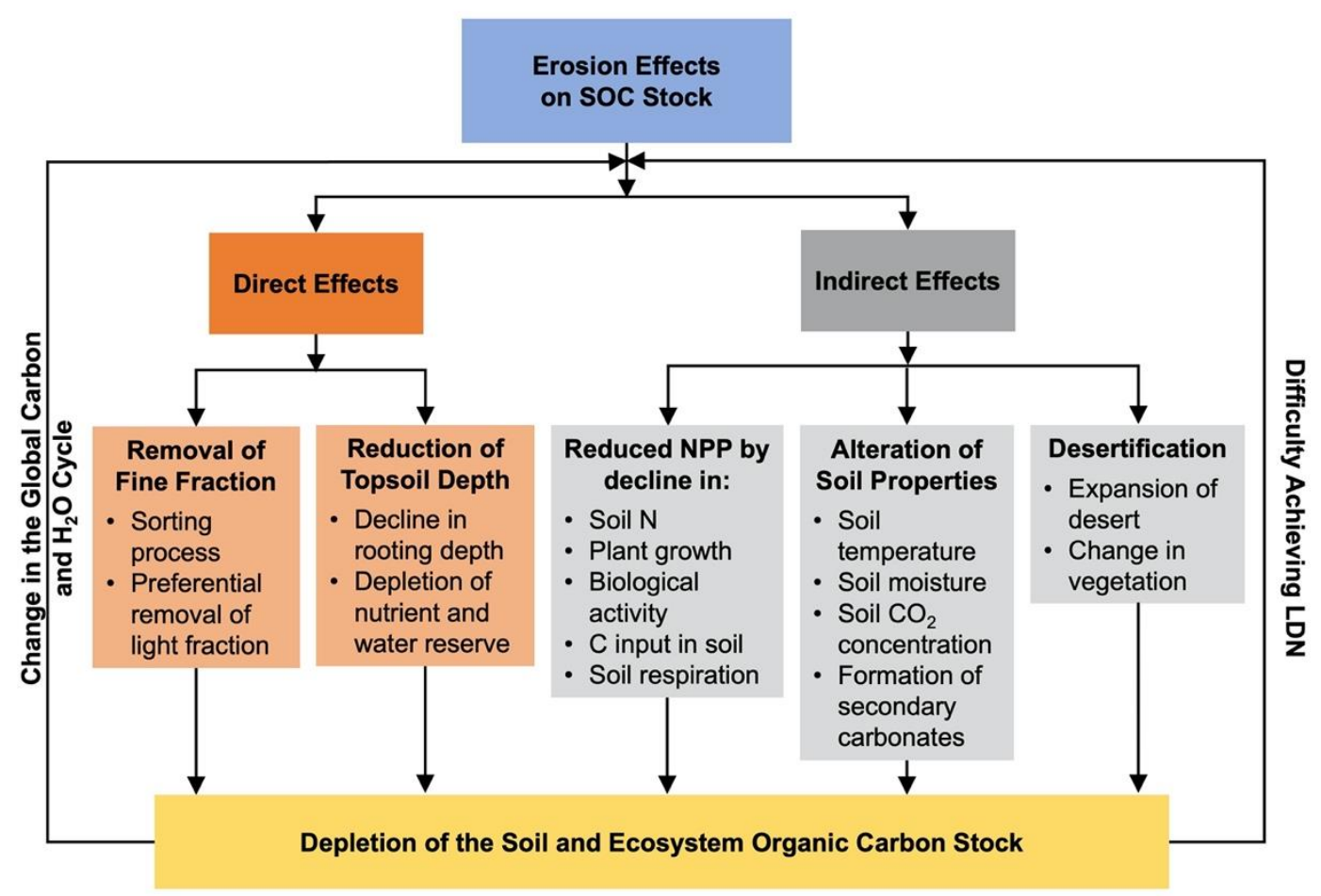

Figure 3. Effects of accelerated soil erosion on the global carbon cycle and the increase in the daunting challenge of achieving land degradation neutrality.

Table 1. Examples of regional, national, or global terrestrial soil organic carbon (SOC) erosion by water and other processes.

\begin{tabular}{ccccc}
\hline Country/Region & $\begin{array}{c}\text { Study } \\
\text { Duration (yr) }\end{array}$ & SOC Erosion & $\begin{array}{c}\text { Erosion } \\
\text { Types }\end{array}$ & References \\
\hline Australia & 40 & $4 \mathrm{Tg} \mathrm{SOC} / \mathrm{yr}$. & all processes & {$[25]$} \\
Burkina Faso & - & $0.15-0.37 \mathrm{~g} \mathrm{C} / \mathrm{m}^{2} \cdot \mathrm{yr}$. & Water & {$[16]$} \\
China & 20 & $180 \pm 80 \mathrm{Mg} \mathrm{C} / \mathrm{yr}$. & Water & {$[26]$} \\
European Union & - & $0.05-0.45 \mathrm{Mg} \mathrm{C} /$ ha.yr. & Water & {$[24]$} \\
Global & - & $1.32 \pm 2 \mathrm{Gt} \mathrm{C/yr.} \mathrm{by} \mathrm{sheet}$ & Water & {$[18]$} \\
Global & - & erosion & Water & {$[10]$} \\
Global & 150 & $0.49 \pm 0.12 \mathrm{Pg} \mathrm{C} / \mathrm{yr}$. & Water & {$[27]$} \\
India & - & $115.4 \mathrm{Tg} \mathrm{C/yr.}$ & Water & {$[28]$} \\
Spain & - & $0.031 \pm 0.03 \mathrm{Mg} \mathrm{C} / \mathrm{ha} \cdot \mathrm{yr}$. & Water & {$[14]$} \\
Turkey (Seyhan & - & $0.19 \mathrm{Mg} \mathrm{C/ha \cdot yr.}$ & Water & {$[29]$} \\
River Basin) & - & & & \\
\hline
\end{tabular}

The SOC being eroded is either deposited in the landscape, in the channel, or carried into the ocean (Figure 2). Some of the $\mathrm{SOC}$ being transported is emitted into the atmosphere as $\mathrm{CO}_{2}$ or $\mathrm{CH}_{4}$, depending on the degree of wetness or anaerobiosis. In China, Fang et al. [17] observed that $42 \%$ of the eroded SOC was redeposited within the catchment. The mean residence time (MRT) of the deposited C depends on a range of site-specific factors, and the fraction composition (labile, intermediate, passive) of the eroded SOC. Wang et al. [30] reported that cumulative emission of soil $\mathrm{CO}_{2}$ decreased slightly at the erosion site but increased by $56 \%$ and $27 \%$ at the transport and depositional zones, respectively, in comparison to non-eroded sites. Wang and colleagues concluded that overall, $\mathrm{CO}_{2}$ emissions contributed $90.5 \%$ of the total erosion-induced C loss over the 4-month experiment. Whereas buried SOC at depositional sites may have a higher MRT even for the fast and intermediate turnover pools [31], 
susceptibility to decomposition may be much higher for the labile fractions redistributed within the landscape.

Examples of the magnitude of SOC erosion by water from different regions are shown in Table 1 and may range from 1.1 to1.3 Pg C per year. The preferential removal of SOC by water erosion is indicated by a high enrichment ratio of SOC (and clay) in sediments compared to that of the surface soil from which the sediments originated. Consequently, the enrichment ratio for SOC in alluvial sediments is $>1$ and may be as high as 12 (Table 2). Erosional processes lead to a preferential transport of SOC because it has a low bulk density and is concentrated in the surface soil layer. In cases where sediments are derived from subsoil (i.e., gully erosion), the enrichment ratio can be less than 1 [32].

There are a few studies involving techniques of quantitative measurement of SOC/TC transported by erosion from a watershed or a well-demarcated area. In Australia, Chappell et al. [25] estimated the magnitude of ${ }^{137} \mathrm{Cs}$-derived redistribution of SOC by all processes (water, wind, and tillage) at $4 \mathrm{Tg}$ SOC/yr for 1950-1990s. This represents an average loss of $2 \%$ of TC stock, assuming that total C is mineralized as $\mathrm{CO}_{2}$, and would represent a net national flux of $15 \mathrm{Tg} \mathrm{CO}_{2} \mathrm{eq} / \mathrm{yr}$ from all C pools in Australia. In a follow-up study, Chappell et al. [33] estimated the global terrestrial SOC erosion at 0.3-1.0 Pg C/yr. For the Seyhan River Basin in the Mediterranean region of Turkey, the rate of SOC erosion was estimated at $\sim 0.2 \mathrm{Mg} \mathrm{C} / \mathrm{ha} \cdot \mathrm{yr}$ [20].

Table 2. The enrichment ratio of carbon in sediments derived from water erosion.

\begin{tabular}{cccc}
\hline Country & Experiment & Enrichment Ratio & Reference \\
\hline Australia & Rainfall simulation & $>1$ & {$[34]$} \\
Belgium & Rainfall simulation & $1.2-3.0$ & {$[35]$} \\
Belgium & Rainfall simulation & $0.9-2.6$ & {$[36]$} \\
China & Lab studies & $1.3-4.0$ & {$[37]$} \\
China & Rainfall simulation & $0.98-1.01$ & {$[32]$} \\
USA & Field experiment under cotton & $8-12$ & {$[38]$} \\
\hline
\end{tabular}

\subsection{Wind Erosion}

Wind erosion, affecting about 550 million hectares of the global land area [11,39], is caused by aeolian (or eolian) processes. The term "aeolian" is derived from the Greek god "Aeolus", the keeper of the wind. Wind erosion is strongly affected by soil texture. Soils most susceptible to wind erosion may have $<5 \%$ clay and $<3 \%$ silt, and $>50 \mathrm{~cm}$ deep surface layer [22]. Wind erosion may create 500-5000 Tg (million tons) of dust annually with a strong impact on soil properties, air quality, and human health [39-41]. The environmental impacts of wind erosion during the Dust Bowl Era of 1931 through 1939 are described by Steinbeck [42].

Accelerated erosion affects critical biotic and abiotic processes governing the soil/ecosystem C cycle. The magnitude of the loss of SOC by wind erosion is related to that of the fine soil fraction [43]. The loss of C-enriched fine soil particles depletes its SOC and reduces its future potential to restore the SOC pool. The aeolian erosion process affects both progressive and regressive pedogenesis in dry eco-regions. On agricultural lands, erosion degrades soil quality by removal of silt, clay, and SOC fractions through effective sorting processes that leave behind only coarse sand and gravels [23]. The loss of NPP reduces the plant feedback and aggravates the SOC loss [44].

The wind-blown dust is also enriched in SOC, which may also depend on soil texture. The global estimate of SOC erosion by wind may be as much as 0.3 to $1.0 \mathrm{Pg} \mathrm{C} / \mathrm{Yr}$ (Table 3) and some highly vulnerable soils may lose $3.6 \mathrm{Mg}$ C/ha per year [32]. Losses of SOC by wind erosion in Northern China are estimated at $0.9 \mathrm{Tg} \mathrm{C} / \mathrm{yr}$ [45]. The loss of PM10 (particles of $<10$ micrometer) adversely impacts soil nutrient reserves [40]. Wind-blown dust is also enriched in SOC and has a high enrichment ratio (Table 4). In Niger, Sterk et al. [46] assessed nutrient and C losses in saltation and suspension transport by conducting chemical analysis of the trapped material at $0.05,0.26,0.5$, and $2 \mathrm{~m}$. The sediments were three times richer than topsoil at $0.5 \mathrm{~m}$ and 17 times at $2 \mathrm{~m}$. In Australia, Webb et al. [47] observed that 
the SOC-enrichment ratio ranged from 2.1-41.9 for a sandy and 2.1 for clayey soil (Table 4). Webb and colleagues hypothesized that in addition to particle size, distribution, and the degree of aggregation, size-selective sorting of SOC during transport may enhance the enrichment of SOC dust emissions. The SOC concentration in two of the dust samples was $15 \%-20 \%$ by weight. A study in China by Ravi et al. [48] documented that an increase in the particulate matter emissions (e.g., black earth) from biochar-amended soils may counteract the negative emissions potential of biochar. Magnitude of dust emitted is aggravated by human activities [40].

Table 3. Examples of regional, national, or global terrestrial SOC erosion by wind.

\begin{tabular}{ccccc}
\hline Country/Region & Study Duration (yr) & SOC Erosion & Erosion Types & References \\
\hline Australia & - & $3.6 \mathrm{Mg} \mathrm{C} / \mathrm{ha}$ & wind & {$[22]$} \\
China & $1-3$ & $34-39 \mathrm{Tg} \mathrm{C} / \mathrm{yr}$. & wind & {$[30]$} \\
China & $10(1990 \mathrm{~s})$ & $75 \mathrm{Tg} \mathrm{C}$ over $10 \mathrm{yr}$. & wind & {$[49]$} \\
China & $56(1954-2010)$ & $92.8 \mathrm{~kg} \mathrm{C} / \mathrm{ha} \cdot \mathrm{yr}$. & wind & {$[17]$} \\
China (NW China) & $34(1980-2013)$ & $27.5 \mathrm{Tg} \mathrm{C}$ & wind & {$[44]$} \\
Global & 100 & $0.3-1.0 \mathrm{Pg} \mathrm{C} / \mathrm{yr}$. & wind & {$[50]$} \\
Hungary & $10 \mathrm{~min}$ & $2.25-2.50 \mathrm{~g} \mathrm{C} / \mathrm{m}^{2}$ & wind & {$[51]$} \\
\hline
\end{tabular}

Table 4. The enrichment ratio of carbon in sediments derived from wind erosion.

\begin{tabular}{cccc}
\hline Country & Experiment & Enrichment Ratio & Reference \\
\hline Australia & Field experiments & $1.7-7.1$ & {$[47]$} \\
Australia & Field sites & $2.1-41.9$ sand-rich soil & {$[52]$} \\
Canada & Field sites & 2.1 clay soil & {$[53]$} \\
\hline
\end{tabular}

Both direct and indirect effects of accelerated erosion, especially in arid and semi-arid regions, exacerbate the risks of desertification and drastically increase the already daunting challenge of achieving land degradation neutrality or LDN by 2030 [54,55]. Soil degradation impacts of accelerated erosion by wind, and its positive feedback to the process of desertification, have strong adverse consequences on Earth systems and human environments [40], as well as on NPP, the input of biomass-C into the soil, and on the disruption of the global C cycle. Thus, achieving LDN would necessitate the global adoption of conservation-effective measures that reduce risks of both aeolian and alluvial processes of soil erosion [56]. Soil restoration strategies must be directed towards increasing the input of biomass-C into the soil. Increase in NPP, and the attendant increase in the input of biomass-C into soil, would restore SOC stock [57]. Dust emission caused by wind erosion may be aggravated by the projected climate change. Thus, Duniway et al. [58] recommended multidisciplinary and multijurisdictional approaches and perspectives to understand the complex processes of dust emission and identify strategies of its mitigation.

\subsection{Gaseous Emissions from Eroded Sediments and the Fate of Carbon Transported and Deposited over the Landscape}

Soil $\mathrm{C}$ stock is an important component of the global $\mathrm{C}$ cycle. The historic $\mathrm{C}$ loss from soil may have emitted as much as $537 \mathrm{Pg} \mathrm{C}$ or $27 \%$ of the amount present before the onset of agriculture about 10 millennia ago [59]. Erosion and redistribution disturb a large quantity of soil $C$ in managed and natural landscapes. The fate of soil $\mathrm{C}$ impacted by erosion may differ among the sites of erosion, redistribution, and deposition (Figure 2). Some examples of gaseous emissions from eroded and depositional sites are shown in (Table 5) [60,61]. Assuming an average flux of $300 \mathrm{mg} \mathrm{CO} \mathrm{Ce}_{2} / \mathrm{m}^{2} \cdot \mathrm{h}$ based on literature review, Oertel et al. [62] estimated the global annual net soil emissions at $\geq 350 \mathrm{Pg} \mathrm{CO}_{2} \mathrm{e}$, as compared with the 2018 anthropogenic emission of $42.1 \mathrm{Pg} \mathrm{CO}_{2} \mathrm{e}$ [21]. However, the large emissions from soil $\mathrm{C}$ transported by aeolian and alluvial processes are not considered in the global $\mathrm{C}$ budget 
(GCB), which creates a lot of uncertainty. Nonetheless, understanding, managing, and reducing the erosion-induced gaseous flux of $\mathrm{CO}_{2}, \mathrm{CH}_{4}$, and $\mathrm{N}_{2} \mathrm{O}$ (Figure 2) is an important researchable priority to reduce uncertainty in the GCB. It is also critical to identify hot spots (vulnerability, resilience, and action), and plans of targeted interventions for managing the flux [63]. Several pedological processes impacted by erosion also affect NPP through alterations in availability and uptake of water, nutrients, and photosynthesis. Credible assessment of $C$ dynamics in agricultural and other landscapes is important to addressing global issues [19]. In a Mediterranean Seyhan river basin, Cilek [29] estimated SOC erosion of $0.163 \mathrm{Mg} \mathrm{C} /$ ha yr. (total SOC loss of $349,850 \mathrm{Mg}$ C/yr. over a total watershed area of $21,485 \mathrm{~km}^{2}$ ). Based on the assessment of nine river basins in China, Wang et al. [30] found that total SOC erosion was 68.4 and $77.3 \mathrm{Tg}$ C/yr. for 1995-1996 and 2010-2012, respectively. Of this, $57 \%$ and $47 \%$ were redistributed over land, $25 \%$ and $44 \%$ was deposited in channels, and $18 \%$ and $8 \%$ were delivered into the sea, respectively. However, how much and which gases were emitted were not determined. For the period A.D. 1850-2005, Naipal et al. [27] estimated global SOC flux of $47 \pm 18 \mathrm{Pg}$ C, of which $79 \%-85 \%$ occurs on agricultural and grasslands.

Table 5. Examples of gaseous emission from eroded sediments and disrupted/broken aggregates by erosional processes.

\begin{tabular}{cccc}
\hline Country & Experiment & Emission & Reference \\
\hline U.K. & Field & $\begin{array}{c}\text { Emission factor of 5.5, 4.4., and } 0.3 \mathrm{Mg} \mathrm{CO}_{2} \\
\mathrm{Eq} / \mathrm{yr} \text { Mg of fluvial C, gross C erosion, and gross soil } \\
\text { erosion, respectively }\end{array}$ & {$[60]$} \\
\hline South Africa & Simulated Rain & $0.031-0.039 \mathrm{gC} \mathrm{CO}_{2} / \mathrm{g} \mathrm{C}$ & {$[61]$} \\
\hline
\end{tabular}

\subsection{Implications of Ignoring Erosion Induced Transport of Carbon in Estimating Global Carbon Budget}

Erosion-induced transport of soil C (SOC and SIC) is a large and growing component with a strong impact on the GCB, but which is now being omitted [21]. However, the erosion-induced impact on soil $\mathrm{C}$ stock and flux, a large component comprising of multiple gases $\left(\mathrm{CO}_{2}, \mathrm{CH}_{4}, \mathrm{~N}_{2} \mathrm{O}\right)$ and multiple processes (e.g., water, wind, gravity, and tillage), must be dually considered. High-resolution models [20] must be developed to improve methodological protocols to account for this serious omission. By credibly accounting for the effects of erosion on net $C$ exchange between the soil and the atmosphere, it may be possible to identify global hot spots of undertaking targeted interventions to mitigate the erosion-induced positive feedback to global warming. In Australia, Chappell et al. [25] found SOC erosion by all processes at $4 \mathrm{Tg} / \mathrm{yr}$. (or $2 \%$ of total C stock in $10-\mathrm{cm}$ depth). Assuming that most of this is mineralized, Chappell and colleagues estimated a flux of $\sim 15 \mathrm{Tg} \mathrm{CO}_{2}$ e/yr. representing $12 \%$ emissions from all C pools in Australia and concluded that it was an important source of uncertainty in the national carbon budget. By extending this study globally, Chappell et al. [50] estimated global terrestrial SOC erosion of $0.3-1.0 \mathrm{Pg} \mathrm{C} / \mathrm{yr}$, highlighted the significance of ignoring it in the accounting of the GCB, and suggested that accounting for SOC erosion would reduce uncertainty in the GCB.

\section{Conservation: Effective Measures for Reducing SOC Erosion and Afforestation of Eroded Lands for Sequestration of Atmospheric $\mathrm{CO}_{2}$ in the Terrestrial Biosphere}

During the 1950s to 1990s, the objective of erosion control was to conserve soil and water, reduce the loss of soil fertility, and minimize the risks of non-point source pollution. Since the 1990s, two among important objectives of soil conservation and effective erosion control measures are to: (1) promote low-C agriculture (9), reduce risks of water runoff and soil erosion so that the attendant emission of GHGs can also be reduced from SOC erosion, and (2) to sequester atmospheric $\mathrm{CO}_{2}$ in soil and vegetation through the restoration of eroded soils and desertified ecosystems. Examples of technological options to accomplish these include the adoption of conservation agriculture including no-till farming with retention of crop residue mulch [4,64-67] and use of cover cropping during the off-season [68] that reduce the risks of water runoff [69], boost SOC stock for food and climate [8,67], and 
curtail transport of SOC and nutrient-enriched sediments [70] for accomplishing objective 1. Similarly, promoting afforestation [71] and adopting the concept of "Reducing Emissions from Deforestation and Forest Degradation or REDD [72] through afforestation of degraded soils [73], and establishments of shelterbelts in areas prone to wind erosion [74-76] would be pertinent to advancing objective 2 of sequestration of atmospheric $\mathrm{CO}_{2}$ in the terrestrial biosphere.

\section{Conclusions}

The synthesis and a critical review of the literature presented above indicate that the hypothesis of the study is proven. Over and above the offsite effect of sedimentation and non-point source pollution, accelerated soil erosion is also an important source of major GHGs $\left(\mathrm{CO}_{2}, \mathrm{CH}_{4}\right.$, and $\left.\mathrm{N}_{2} \mathrm{O}\right)$ emitted during all three stages of the erosion process.

The discussion presented has also led to accomplishing the major objectives of the study:

1. Accelerated soil erosion (i.e., water, wind, and other processes) has a strong impact on the GCB. Soil carbon transported by erosional processes is partitioned as follows: (i) redistribution over the landscape, (ii) deposition in channels and other depressional sites, and (iii) transportation into the oceans. Because the eroded site is depleted of its SOC stock, its NPP is adversely affected, and the gaseous flux from soil to the atmosphere is decreased. Depending on the soil temperature and moisture regimes, gaseous fluxes (e.g., $\mathrm{CO}_{2}, \mathrm{CH}_{4}$, and $\mathrm{N}_{2} \mathrm{O}$ ) from redistribution and depositional sites may increase.

2. The magnitude of soil $\mathrm{C}$ transported by water erosion may be $10 \%-15 \%$ of the total anthropogenic emissions of $\sim 11.5 \mathrm{Pg}$ in 2019. In addition, there is a large transport by wind erosion in arid and semi-arid climates. Such a large flux, with severe negative impacts on NPP and other biotic and abiotic processes, must be accounted for in the GCB. Considering the multi-gas flux $\left(\mathrm{CO}_{2}, \mathrm{CH}_{4}\right.$, and $\mathrm{N}_{2} \mathrm{O}$ ), and the fact that some gases have a large global warming potential $\left(\mathrm{CH}_{4}\right.$ and $\left.\mathrm{N}_{2} \mathrm{O}\right)$, the magnitude of erosion-induced flux of GHGs must be accounted for and included along with those of other anthropogenic activities affecting global warming.

3. The SOC erosion by water and wind accelerates anthropogenic climate change and also decreases soils' $\mathrm{C}$ sink capacity to mitigate global warming. Thus, accelerated soil erosion must be effectively managed to minimize the risks. Eroded soils, which are already severely depleted of their SOC stock, must be restored to improve soil health and enhance essential ecosystem services. Adoption of conservation-effective measures for restoration of eroded soils may represent a net significant carbon sink.

4. Additional research is needed on developing methodologies to account for the SOC erosion into the GCB.

5. Because SOC erosion is a source of multiple GHGs, erosion-induced emissions as $\mathrm{CO}_{2}$ eq must be considered among the sources of anthropogenic emissions.

6. Adoption of site/region-specific conservation-effective technologies (conservation agriculture, mulch farming, cover cropping, afforestation, REDD, and shelterbelts) must be promoted to conserve soil and water and reduce the emission of erosion-induced GHGs.

Funding: This research received no external funding.

Acknowledgments: Support received from Maggie Willis and Kyle Sklenka, the staff of the Carbon Management and Sequestration Center of the Ohio State University, is appreciated and acknowledged.

Conflicts of Interest: The authors declare no conflict of interest.

\section{References}

1. Robert, J. Human Activities Boosted Global Soil Erosion Already 4000 years ago. Available online: https://www.eurekalert.org/pub_releases/2019-10/indl-hab102919.php (accessed on 23 March 2020).

2. Montgomery, D.R. Dirt: The Erosion of Civilizations; University of California Press: Berkeley, CA, USA, 2007; ISBN 9780520248700. 
3. Diamond, J.M. Collapse: How Societies Choose To Fail Or Succeed; Viking: New York, NY, USA, 2005; ISBN 978-0143117001.

4. Borrelli, P.; Paustian, K.; Panagos, P.; Jones, A.; Schütt, B.; Lugato, E. Effect of good agricultural and environmental conditions on erosion and soil organic carbon balance: A national case study. Land Use Policy 2016, 50, 408-421. [CrossRef]

5. Routschek, A.; Schmidt, J.; Kreienkamp, F. Impact of climate change on soil erosion-A high-resolution projection on catchment scale until 2100 in Saxony/Germany. Catena 2014, 121, 99-109. [CrossRef]

6. Harrabin, R. Soil Erosion Accelerates Climate Change, Impacting 3.2 Billion People, UN Report Claims. Available online: https://geneticliteracyproject.org/2019/04/30/soil-erosion-accelerates-climatechange-impacting-3-2-billion-people-un-report-claims/ (accessed on 23 March 2020).

7. Lal, R. Digging deeper: A holistic perspective of factors affecting soil organic carbon sequestration in agroecosystems. Glob. Chang. Biol. 2018, 24, 3285-3301. [CrossRef]

8. Rumpel, C.; Lehmann, J.; Chabbi, A. Boost soil carbon for food and climate. Nature 2018, 553, 27. [CrossRef]

9. de Moraes Sá, J.C.; Lal, R.; Cerri, C.C.; Lorenz, K.; Hungria, M.; de Faccio Carvalho, P.C. Low-carbon agriculture in South America to mitigate global climate change and advance food security. Environ. Int. 2017, 98, 102-112. [CrossRef] [PubMed]

10. Lal, R. Soil erosion and the global carbon budget. Environ. Int. 2003, 29, 437-450. [CrossRef]

11. Oldeman, L. The global extent of land degradation. In Land Resilience and Sustainable Land Use; Greenland, D.J., Szabolcs, I., Eds.; CABI: Wallingford, UK, 1994; pp. 99-118.

12. Walling, D.E. The Impact of Global Change on Erosion and Sediment Transport by Rivers: Current Progress and Future Challenges; The United Nations Educational, Scientific and Cultural Organization: Paris, France, 2009.

13. Yang, D.; Kanae, S.; Oki, T.; Koike, T.; Musiake, K. Global potential soil erosion with reference to land use and climate changes. Hydrol. Process. 2003, 17, 2913-2928. [CrossRef]

14. Boix-Fayos, C.; Martínez-Mena, M.; Cutillas, P.P.; de Vente, J.; Barberá, G.G.; Mosch, W.; Navarro Cano, J.A.; Gaspar, L.; Navas, A. Carbon redistribution by erosion processes in an intensively disturbed catchment. Catena 2017, 149, 799-809. [CrossRef]

15. Lugato, E.; Smith, P.; Borrelli, P.; Panagos, P.; Ballabio, C.; Orgiazzi, A.; Fernandez-Ugalde, O.; Montanarella, L.; Jones, A. Soil erosion is unlikely to drive a future carbon sink in Europe. Sci. Adv. 2018, 4, eaau3523. [CrossRef] [PubMed]

16. Maïga-Yaleu, S.; Guiguemde, I.; Yacouba, H.; Karambiri, H.; Ribolzi, O.; Bary, A.; Ouedraogo, R.; Chaplot, V. Soil crusting impact on soil organic carbon losses by water erosion. Catena 2013, 107, 26-34. [CrossRef]

17. Fang, H.; Li, Q.; Sun, L.; Cai, Q. Using 137Cs to study spatial patterns of soil erosion and soil organic carbon (SOC) in an agricultural catchment of the typical black soil region, Northeast China. J. Environ. Radioact. 2012, 112, 125-132. [CrossRef] [PubMed]

18. Müller-Nedebock, D.; Chaplot, V. Soil carbon losses by sheet erosion: A potentially critical contribution to the global carbon cycle. Earth Surf. Process. Landforms 2015, 40, 1803-1813. [CrossRef]

19. Kirkels, F.M.S.A.; Cammeraat, L.H.; Kuhn, N.J. The fate of soil organic carbon upon erosion, transport and deposition in agricultural landscapes-A review of different concepts. Geomorphology 2014, 226, 94-105. [CrossRef]

20. Dialynas, Y.G.; Bastola, S.; Bras, R.L.; Billings, S.A.; Markewitz, D.; deB. Richter, D. Topographic variability and the influence of soil erosion on the carbon cycle. Glob. Biogeochem. Cycles 2016, 30, 644-660. [CrossRef]

21. Friedlingstein, P.; Jones, M.W.; O'Sullivan, M.; Andrew, R.M.; Hauck, J.; Peters, G.P.; Peters, W.; Pongratz, J.; Sitch, S.; Le Quéré, C.; et al. Global carbon budget 2019. Earth Syst. Sci. Data 2019, 11, 1783-1838. [CrossRef]

22. Harper, R.; Gilkes, R.; Hill, M.; Carter, D. Wind erosion and soil carbon dynamics in south-western Australia. Aeolian Res. 2010, 1, 129-141. [CrossRef]

23. Buschiazzo, D.; Funk, R. Wind Erosion of Agricultural Soils and the Carbon Cycle. In Soil Carbon Science, Management and Policy for Multiple Benefits; European Commission Directorate Gen. Joint Res. Ctr.: Ispra, Italy, 2015; pp. 161-168.

24. Lugato, E.; Paustian, K.; Panagos, P.; Jones, A.; Borrelli, P. Quantifying the erosion effect on current carbon budget of European agricultural soils at high spatial resolution. Glob. Chang. Biol. 2016, 22, 1976-1984. [CrossRef] 
25. Chappell, A.; Webb, N.P.; Viscarra Rossel, R.A.; Bui, E. Australian net (1950s-1990) soil organic carbon erosion: Implications for $\mathrm{CO}_{2}$ emission and land-atmosphere modelling. Biogeosciences 2014, 11, 5235-5244. [CrossRef]

26. Yue, Y.; Ni, J.; Ciais, P.; Piao, S.; Wang, T.; Huang, M.; Borthwick, A.G.L.; Li, T.; Wang, Y.; Chappell, A.; et al. Lateral transport of soil carbon and land-atmosphere $\mathrm{CO}_{2}$ flux induced by water erosion in China. Proc. Natl. Acad. Sci. USA 2016, 113, 6617-6622. [CrossRef]

27. Naipal, V.; Ciais, P.; Wang, Y.; Lauerwald, R.; Guenet, B.; Van Oost, K. Global soil organic carbon removal by water erosion under climate change and land use change during AD 1850-2005. Biogeosciences 2018, 15, 4459-4480. [CrossRef]

28. Mandal, D.; Giri, N.; Srivastava, P. The magnitude of erosion-induced carbon (C) flux and C-sequestration potential of eroded lands in India. Eur. J. Soil Sci. 2020, 71, 151-168. [CrossRef]

29. Cilek, A. Soil organic carbon losses by water erosion in a Mediterranean watershed. Soil Res. 2017, 55, 363-375. [CrossRef]

30. Wang, X.; Quine, T.A.; Zhang, H.; Tian, G.; Yuan, W. Redistribution of Soil Organic Carbon Induced by Soil Erosion in the Nine River Basins of China. J. Geophys. Res. Biogeosciences 2019, 124, 1018-1031. [CrossRef]

31. Doetterl, S.; Six, J.; Van Wesemael, B.; Van Oost, K. Carbon cycling in eroding landscapes: Geomorphic controls on soil organic C pool composition and C stabilization. Glob. Chang. Biol. 2012, 18, 2218-2232. [CrossRef]

32. Li, Z.; Nie, X.; Chang, X.; Liu, L.; Sun, L. Characteristics of soil and organic carbon loss induced by water erosion on the loess plateau in China. PLOS ONE 2016, 11.

33. Chappell, A.; Baldock, J.; Sanderman, J. The global significance of omitting soil erosion from soil organic carbon cycling schemes. Nat. Clim. Chang. 2016, 6, 187-191. [CrossRef]

34. Palis, R.G.; Ghandiri, H.; Rose, C.W.; Saffigna, P.G. Soil erosion and nutrient loss. III. Changes in the enrichment ratio of total nitrogen and organic carbon under rainfall detachment and entrainment. Aust. J. Soil Res. 1997, 35, 891-905. [CrossRef]

35. Wang, Z.; Govers, G.; Steegen, A.; Clymans, W.; Van den Putte, A.; Langhans, C.; Merckx, R.; Van Oost, K. Catchment-scale carbon redistribution and delivery by water erosion in an intensively cultivated area. Geomorphology 2010, 124, 65-74. [CrossRef]

36. Schiettecatte, W.; Gabriels, D.; Cornelis, W.M.; Hofman, G. Enrichment of Organic Carbon in Sediment Transport by Interrill and Rill Erosion Processes. Soil Sci. Soc. Am. J. 2008, 72, 50-55. [CrossRef]

37. Wang, X.; Cammeraat, E.L.H.; Romeijn, P.; Kalbitz, K. Soil organic carbon redistribution by water erosion-The role of $\mathrm{CO}_{2}$ emissions for the carbon budget. PLoS ONE 2014, 9.

38. Endale, D.M.; Potter, T.L.; Strickland, T.C.; Bosch, D.D. Sediment-bound total organic carbon and total organic nitrogen losses from conventional and strip tillage cropping systems. Soil Tillage Res. 2017, 171, 25-34. [CrossRef]

39. Zobeck, T.M.; Van Pelt, R.S. Wind Erosion. In Soil Management: Building a Stable Base for Agriculture; Soil Science Society of America: Madison, WI, USA, 2011; pp. 209-227.

40. Katra, I. Soil Erosion by Wind and Dust Emission in Semi-Arid Soils Due to Agricultural Activities. Agronomy 2020, 10, 89. [CrossRef]

41. Grini, A.; Myhre, G.; Zender, C.S.; Isaksen, I.S.A. Model simulations of dust sources and transport in the global atmosphere: Effects of soil erodibility and wind speed variability. J. Geophys. Res. D Atmos. 2005, 110, 1-14. [CrossRef]

42. Steinbeck, J. Steinbeck—The Grapes of Wrath; The Viking Press: New York, NY, USA, 1939.

43. Li, P.; Liu, L.; Wang, J.; Wang, Z.; Wang, X.; Bai, Y.; Chen, S. Wind erosion enhanced by land use changes significantly reduces ecosystem carbon storage and carbon sequestration potentials in semiarid grasslands. L. Degrad. Dev. 2018, 29, 3469-3478. [CrossRef]

44. Lei, L.; Zhang, K.; Zhang, X.; Wang, Y.P.; Xia, J.; Piao, S.; Hui, D.; Zhong, M.; Ru, J.; Zhou, Z.; et al. Plant Feedback Aggravates Soil Organic Carbon Loss Associated With Wind Erosion in Northwest China. J. Geophys. Res. Biogeosciences 2019, 124, 825-839. [CrossRef]

45. Du, H.; Wang, T.; Xue, X.; Li, S. Estimation of soil organic carbon, nitrogen, and phosphorus losses induced by wind erosion in Northern China. L. Degrad. Dev. 2019, 30, 1006-1022. [CrossRef]

46. Sterk, G.; Herrmann, L.; Bationo, A. Wind-blown nutrient transport and soil productivity changes in southwest Niger. L. Degrad. Dev. 1996, 7, 325-335. [CrossRef] 
47. Chappell, A.; Webb, N.; Butler, H.; Strong, C.; McTainsh, G.; Leys, J.; Viscarra Rossel, R. Soil organic carbon dust emission: An omitted global source of atmospheric $\mathrm{CO}_{2}$. Glob. Chang. Biol. 2013, 19, 3238-3244. [CrossRef]

48. Ravi, S.; Sharratt, B.S.; Li, J.; Olshevski, S.; Meng, Z.; Zhang, J. Particulate matter emissions from biochar-amended soils as a potential tradeoff to the negative emission potential. Sci. Rep. 2016, 6, 1-7. [CrossRef]

49. Yan, H.; Wang, S.; Wang, C.; Zhang, G.; Patel, N. Losses of soil organic carbon under wind erosion in China. Glob. Chang. Biol. 2005, 11, 828-840. [CrossRef]

50. Chappell, A.; Baldock, J. Wind erosion reduces soil organic carbon sequestration falsely indicating ineffective management practices. Aeolian Res. 2016, 22, 107-116. [CrossRef]

51. Farsang, A.; Duttmann, R.; Bartus, M.; Szatmári, J.; Barta, K.; Bozsó, G. Estimation of Soil Material Transportation by Wind Based on in Situ Wind Tunnel Experiments. J. Environ. Geogr. 2013, 6, 13-20. [CrossRef]

52. Webb, N.P.; Chappell, A.; Strong, C.L.; Marx, S.K.; McTainsh, G.H. The significance of carbon-enriched dust for global carbon accounting. Glob. Chang. Biol. 2012, 18, 3275-3278. [CrossRef]

53. Larney, F.J.; Bullock, M.S.; Janzen, H.H.; Ellert, B.H.; Olson, E.C.S. Wind erosion effects on nutrient redistribution and soil productivity. J. Soil Water Conserv. 1998, 53, 133-140.

54. Stavi, I.; Lal, R. Achieving Zero Net Land Degradation: Challenges and opportunities. J. Arid Environ. 2015, 112, 44-51. [CrossRef]

55. Cowie, A.L.; Orr, B.J.; Castillo Sanchez, V.M.; Chasek, P.; Crossman, N.D.; Erlewein, A.; Louwagie, G.; Maron, M.; Metternicht, G.I.; Minelli, S.; et al. Land in balance: The scientific conceptual framework for Land Degradation Neutrality. Environ. Sci. Policy 2018, 79, 25-35. [CrossRef]

56. Chappell, A.; Webb, N.P.; Leys, J.F.; Waters, C.M.; Orgill, S.; Eyres, M.J. Minimising soil organic carbon erosion by wind is critical for land degradation neutrality. Environ. Sci. Policy 2019, 93, 43-52. [CrossRef]

57. Karmakar, R.; Das, I.; Dutta, D.; Rakshit, A. Potential effects of climate change on soil properties: A review. Sci. Int. 2016, 4, 51-73. [CrossRef]

58. Duniway, M.C.; Pfennigwerth, A.A.; Fick, S.E.; Nauman, T.W.; Belnap, J.; Barger, N.N. Wind erosion and dust from US drylands: A review of causes, consequences, and solutions in a changing world. Ecosphere 2019, 10, e02650. [CrossRef]

59. Buringh, P. Organic Carbon in Soils of the World. In The Role of Terrestrial Vegetation in the Global Carbon Cycle: Measurement by Remote Sensing; John Wiley \& Sons, Ltd.: New York, NY, USA, 1984; pp. 91-109.

60. Worrall, F.; Burt, T.P.; Howden, N.J.K. The fluvial flux of particulate organic matter from the UK: The emission factor of soil erosion. J. Hydrol. 2014, 519, 611-625. [CrossRef]

61. Mchunu, C.; Chaplot, V. Land degradation impact on soil carbon losses through water erosion and $\mathrm{CO}_{2}$ emissions. Geoderma 2012, 177-178, 72-79. [CrossRef]

62. Oertel, C.; Matschullat, J.; Zurba, K.; Zimmermann, F.; Erasmi, S. Greenhouse gas emissions from soils-A review. Geochemistry 2016, 76, 327-352. [CrossRef]

63. Malhi, Y.; Franklin, J.; Seddon, N.; Solan, M.; Turner, M.G.; Field, C.B.; Knowlton, N. Climate change and ecosystems: Threats, opportunities and solutions. Philos. Trans. R. Soc. B Biol. Sci. 2020, 375. [CrossRef] [PubMed]

64. Harrold, L.; Triplett, G.; Youker, R. Watershed tests of no-tillage corn. J. Soil Water Conserv. 1967, $22,98-100$.

65. Harrold, L.L.; Edwards, W.M. Severe rainstorm test of no-till corn. J. Soil Water Conserv. 1972.

66. Lal, R. Soil erosion on Alfisols in Western Nigeria. IV. Nutrient element losses in runoff and eroded sediments. Geoderma 1976, 16, 403-417. [CrossRef]

67. Lal, R. Soil carbon sequestration impacts on global climate change and food security. Science 2004, 304, 1623-1627. [CrossRef]

68. Blanco-Canqui, H.; Shaver, T.M.; Lindquist, J.L.; Shapiro, C.A.; Elmore, R.W.; Francis, C.A.; Hergert, G.W. Cover crops and ecosystem services: Insights from studies in temperate soils. Agron. J. 2015, 107, 2449-2474. [CrossRef]

69. Kaspar, T.C.; Singer, J.W. The Use of Cover Crops to Manage Soil. In Soil Management: Building a Stable Base for Agriculture; Soil Science Society of America: Fitchburg, WI, USA, 2015; pp. 321-337. 
70. Aryal, N.; Reba, M.L.; Straitt, N.; Teague, T.G.; Bouldin, J.; Dabney, S. Impact of cover crop and season on nutrients and sediment in runoff water measured at the edge of fields in the Mississippi Delta of Arkansas. J. Soil Water Conserv. 2018, 73, 24-34. [CrossRef]

71. Pacala, S.; Socolow, R. Stabilization wedges: Solving the climate problem for the next 50 years with current technologies. Science 2004, 305, 968-972. [CrossRef]

72. Goetz, S.J.; Hansen, M.; Houghton, R.A.; Walker, W.; Laporte, N.; Busch, J. Measurement and monitoring needs, capabilities and potential for addressing reduced emissions from deforestation and forest degradation under REDD+. Environ. Res. Lett. 2015, 10, 123001. [CrossRef]

73. Lu, H.; Wang, X.; Zhang, Y.; Yan, W.; Zhang, J. Modelling forest fragmentation and carbon emissions for REDD plus. Procedia Eng. 2012, 37, 333-338. [CrossRef]

74. Bartus, M.; Barta, K.; Szatmári, J.; Farsang, A. Modeling wind erosion hazard control efficiency with an emphasis on shelterbelt system and plot size planning. Z. Geomorphol. 2017, 61, 123-133. [CrossRef]

75. Bird, P.R. Tree windbreaks and shelter benefits to pasture in temperate grazing systems. Agrofor. Syst. 1998, 41, 35-54. [CrossRef]

76. Brandle, J.R.; Hodges, L.; Zhou, X.H. Windbreaks in North American agricultural systems. Agrofor. Syst. 2004, 61-62, 65-78.

(C) 2020 by the author. Licensee MDPI, Basel, Switzerland. This article is an open access article distributed under the terms and conditions of the Creative Commons Attribution (CC BY) license (http://creativecommons.org/licenses/by/4.0/). 